Original Article

\title{
DIVERSITY OF UNDERUTILIZED WILD EDIBLE FRUITS OF KANNUR DISTRICT, KERALA, INDIA
}

\author{
NEHA C. P. , ABDUSSALAM A. K.
}

Department of Post Graduate Studies and Research in Botany, Sir Syed College, Taliparamba, Kannur, 670142 Email: nehasreenivas@gmail.com

Received: 16 Jun 2020, Revised and Accepted: 19 Aug 2020

\section{ABSTRACT}

Objective: To explore, collect, identify and preserve wild edible fruits of Kannur district, Kerala.

Methods: Field survey was conducted for collecting information regarding utilization aspects of some underutilized fruits. The important wild fruits were selected on the basis of their easy availability and on their food and medicinal values in Kannur district.

Results: Total thirty three wild edible fruits were collected, identified, and documented. All these fruits were good source of fat, protein, sugars and antioxidants. Most species were found to have many therapeutic uses.

Conclusion: The documentation of wild fruits will benefit the community through the use of locally and freely available healthy food which will also preserve their cultural pride. And these wild fruit plants have important role in maintaining ecological balance.

Keywords: Antioxidant, Culture, Ecology, Fruits, Medicinal, Underutilized, Wild

(C) 2020 The Authors. Published by Innovare Academic Sciences Pvt Ltd. This is an open access article under the CC BY license (http://creativecommons.org/licenses/by/4.0/) DOI: http://dx.doi.org/10.22159/ijcpr.2020v12i5.39779. Journal homepage: https://innovareacademics.in/journals/index.php/ijcpr

\section{INTRODUCTION}

Wild edible plants represent species that are collected from the surrounding ecosystems for human consumption but are not cultivated. Poor communities throughout the world are dependent on these wild plants for their food, nutrition, subsistence needs and improving rural livelihoods as well [1]. Unfortunately data available on their identification, nutritional properties, use and management or user's preferences is scanty or less documented [2]. Till date 2, $50,000-3,00,000$ higher plant species are documented, of which only a few hundred species are cultivated and a few thousands are gathered from the wild. More than 7000 species of WEPs are documented worldwide [3]. About 1000 species were identified in Americas, 1200 species in Africa and 800 species in Asia [4, 5]. The wild edible fruit species documented in India from Himalayas are more than 675 species [6]. 118 species from Arunachal Pradesh [7], 12 species from Uttara Kannada district of Karnataka [8]. 150 species from Orissa [9], 132 species from Assam [10] and 80 species from Chhattisgarh [11].

Undervaluation, underutilization, high population growth and modern development leading to deforestation have lead to loss of diversity of the wild edible fruit species [12]. In addition to this they are being exploited from wild without any effort to propagate them or any ex situ conservation strategies [13]. Promoting and domesticating these wild fruit species not only will improve nutritional status and improve livelihood of the local communities but also protect them from loosing from the wild and well being of environment [14].

The use of these wild plants for food and other uses by the rural and indigenous communities can be continued by developing harmonious correlation among farming and wild biodiversity [15]. Wild edible Plants which are described in this paper are not very much known to scientific world for their nutritional property. In literature, very low attention was given to verify the nutritional status of these plants. The main objective of this work was to document wild edible fruit plants in different places of Kannur district and bring them in the public attention and interest. So that some of them, during the course of time, may emerge as commercial plant.

\section{MATERIALS AND METHODS}

The present study was carried out in Kannur district, Kerala state, India during the year 2017 to 2018. Repeated collection trips were carried out in different seasons to various localities such as Madayippara, Pazhayangadi, Edakkad, Andaloor kavu, Meloor, Aralam, Mattanur, Kannavam, Kottayampoyil, Taliparamba, Payyanur, Kuppam, Kuttikkol, Valapattanam, Iritty, Kottiyoor, Thalassery of the district. The collected specimens were preserved as herbarium. The specimens were identified with the help of Flora of Gamble, local floras, relevant literature and authentic herbarium collections available in Calicut University.

\section{RESULTS}

During the study it was observed that local people are not much aware of the importance of locally available wild edible plants. And most of the plant species are under high risk, as most of these plants have been destroyed by antropogenic activity. A total of thirty three plant species were identified and documented. These included nineteen trees, ten shrubs and four climbers. The life forms of wild edible plants are represented in the fig. 1 . These 33 wild plants belonged to 15 families. Most of the plants belongs to the family moraceae and euphorbiaceae. The family wise distribution of wild edible fruit plants are represented in fig. 2 .

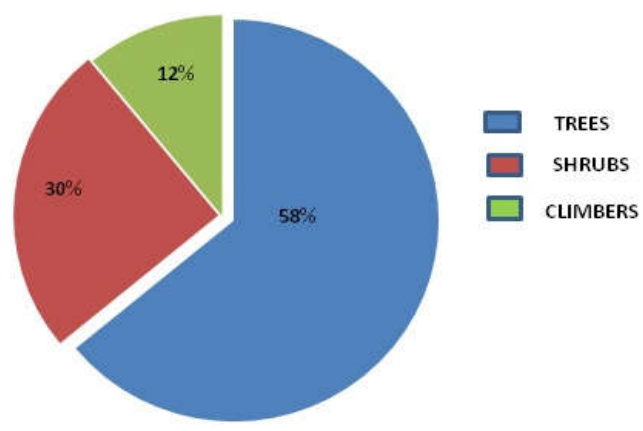

Fig. 1: Life forms of wild edible fruit plants in Kannur district 
Table 1: List of wild edible fruits species of various localities of Kannur district

\begin{tabular}{|c|c|c|c|c|c|c|}
\hline $\begin{array}{l}\text { S. } \\
\text { No. }\end{array}$ & Name of the fruit plant & Family & Habit & $\begin{array}{l}\text { Flowering and } \\
\text { fruiting time }\end{array}$ & Local name & Traditional knowledge \\
\hline 1. & Aegle marmelos correa. & Rutaceae & $\mathrm{T}$ & March-May & Koovalam & Fruits used as raw or cooked \\
\hline 2. & $\begin{array}{l}\text { Ampellocissus indica } \\
\text { (L.)Planch. }\end{array}$ & Vitaceae & $\mathrm{C}$ & March-Sep & Chemparavally & $\begin{array}{l}\text { Eaten directly and used to prepare } \\
\text { pickle }\end{array}$ \\
\hline 3. & Annona glabra L. & Annonaceae & $\mathrm{T}$ & Jan-April & Kattatha & Eaten directly \\
\hline 4. & Annona reticulata $\mathrm{L}$. & Annonaceae & $\mathrm{T}$ & May-Aug & Aatha & Eaten directly \\
\hline 5. & Annona squamosa L. & Annonaceae & $\mathrm{T}$ & June-Oct & Seethapazham & Eaten directly \\
\hline 6. & Antidesma acidum Retz. & Euphorbaceae & S & July-Dec & Asaripuli & Eaten directly and prepare pickle \\
\hline 7. & $\begin{array}{l}\text { Artocarpus gomezianus Wall. } \\
\text { Ex Trecul ssp. Zeylanicus } \\
\text { Jarret. }\end{array}$ & Moraceae & $\mathrm{T}$ & Jan-April & Kaatukadaplavu & Eaten directly \\
\hline 8. & Artocarpus hirsutus Lam. & Moraceae & $\mathrm{T}$ & Dec-March & Aanjili & Eaten directly \\
\hline 9. & Averhhoa carambola $\mathrm{L}$. & Euphorbiaceae & $\mathrm{T}$ & May-Aug & Chathurapuli & Fruits used raw, cooked and pickled \\
\hline 10. & Averrhoa bilimbi L. & Euphorbiaceae & $\mathrm{T}$ & March-May & Bilibi & Eaten directly and pickled \\
\hline 11. & $\begin{array}{l}\text { Baccaurea courtallensis } \\
\text { (Wight)Muell. Arg. }\end{array}$ & Euphorbiaceae & $\mathrm{T}$ & Jan-June & Mootilpazham & Fresh fruits eaten directly \\
\hline 12. & Bridelia retusa (L.)A. Juss. & Euphorbiaceae & $\mathrm{T}$ & Aug-Dec & Mulluvenga & $\begin{array}{l}\text { Fresh fruits are chewed and taken } \\
\text { against mouth ulcers }\end{array}$ \\
\hline 13. & $\begin{array}{l}\text { Broussonetia papyrifera }(\mathrm{L} .) \\
\text { Vent. }\end{array}$ & Moraceae & $\mathrm{T}$ & Nov-Jan & Paper mulberry & Eaten directly \\
\hline 14. & $\begin{array}{l}\text { Canthium coromandelicum } \\
\text { (Burm. f.)Alston }\end{array}$ & Rubiaceae & $\mathrm{T}$ & April-June & Karamullu & $\begin{array}{l}\text { Fresh and dried fruits used against } \\
\text { mouth ulcers }\end{array}$ \\
\hline 15. & Carissa carandas $\mathrm{L}$. & Apocynaceae & S & Jan-June & Karaka & Eaten directly \\
\hline 16. & Cassia fistula $\mathrm{L}$. & Fabaceae & $\mathrm{T}$ & Feb-Sep & Konna & $\begin{array}{l}\text { Dried fruits used for treatement of } \\
\text { stomach problems }\end{array}$ \\
\hline 17. & Chrysophyllum cainito $L$. & Sapotaceae & $\mathrm{T}$ & July-sep & Star Apple & Cooked fruits used for fever \\
\hline 18. & Cissus quadrangularis $\mathrm{L}$. & Vitaceae & $\mathrm{C}$ & June-Jan & Changalamparanda & Eaten directly \\
\hline 19. & $\begin{array}{l}\text { Cyphomandra betacea } \\
\text { (Cav.)Scendt. }\end{array}$ & Solanaceae & S & $\begin{array}{l}\text { Throughout the } \\
\text { year }\end{array}$ & Marathakkali & Eaten directly \\
\hline 20. & Diospyros peregrina Gaertn. & Ebenaceae & $\mathrm{T}$ & March-May & Panachi & Dried fruits used to treat cold \\
\hline 21. & Ficus auriculata Lour. & Moraceae & $\mathrm{T}$ & Nov-Feb & Atthi & Eaten directly and cooked \\
\hline 22. & Ficus racemosa $\mathrm{L}$. & Moraceae & $\mathrm{T}$ & Feb-May & Atthi & Eaten directly \\
\hline 23. & Flacourtia Montana Graham. & Flacourtiaceae & $\mathrm{T}$ & April-June & Charalpazham & $\begin{array}{l}\text { Fresh fruits used to treat digestive } \\
\text { problems }\end{array}$ \\
\hline 24. & Flueggea leucopyrus Willd. & Euphorbiaceae & S & June-Sep & Vellapoolam & Eaten directly \\
\hline 25. & $\begin{array}{l}\text { Glycosmis pentaphylla } \\
\text { (Retz.)DC. }\end{array}$ & Rutaceae & S & Sep-April & Kuttipanal & $\begin{array}{l}\text { Eaten directly and treatment of } \\
\text { stomach worms }\end{array}$ \\
\hline 26. & $\begin{array}{l}\text { Grewia nervosa } \\
\text { (Lour.)Panighrahi }\end{array}$ & Tiliaceae & S & Aug-April & Cheripazham & $\begin{array}{l}\text { Fresh fruit juice used to treat stomach } \\
\text { problems }\end{array}$ \\
\hline 27. & Ixora coccinea $\mathrm{L}$. & Rubiaceae & S & $\begin{array}{l}\text { Throughout the } \\
\text { year }\end{array}$ & Kattuchethi & Ripe fruits used as dietary source \\
\hline 28. & Melastoma malabathricum L. & Melastomaceae & S & $\begin{array}{l}\text { Throughout the } \\
\text { year }\end{array}$ & Athirani & Dried fruits used to low diabetes \\
\hline 29. & Mimusops elengi L. & Sapotaceae & $\mathrm{T}$ & Dec-Aug & Elangi & Fruit juice is anthelmintic \\
\hline 30. & Morus alba $\mathrm{L}$. & Moraceae & S & $\begin{array}{l}\text { Throughout the } \\
\text { year }\end{array}$ & Mulbari & Eaten direstly \\
\hline 31. & $\begin{array}{l}\text { Naringi crenulata (Roxb.) } \\
\text { Nicolson }\end{array}$ & Rutaceae & $\mathrm{T}$ & Dec-June & Kattunarakam & Fruit juice used for heart troubles \\
\hline 32. & Passiflora edulis Sims. & Passifloraceae & $\mathrm{C}$ & $\begin{array}{l}\text { Throughout the } \\
\text { year }\end{array}$ & Passion fruit & Eaten directly, treatment of jaundice \\
\hline 33. & Passiflora foetida $\mathrm{L}$. & Passifloraceae & $\mathrm{C}$ & July-Dec & Poochapazham & Eaten directly \\
\hline
\end{tabular}

T: Tree C: Climber S: Shrub



Fig. 2: Family wise distribution of wild edible fruit plants 


\section{DISCUSSION}

Majority of these fruit are eaten in the ripen stage. Due to the lack of popularity and overexploitation of wild areas these plants are decreasing gradually and some are rarely found. To protect and popularize these wild edible fruits awareness should be needed among people. Studies on nutritional status and medicinal properties are needed for future.

Yeshodharan and Sujana studied wild edible plants traditionally used by tribes of parambikulam wild life sanctuary. Eighty three species were used by tribes as vegetables, wild fruits or in other preparations Analysis of the information revealed that out of 83 species, 82 belongs to Angiosperms and one species belongs to gymnosperm [16]. Aralam wildlife sanctuary is the northernmost protected area in Kerala. The floristic study resulted in recording 1,005 species. The flora of the sanctuary includes 43 wild edible plants of theses 32 are edible fruits, 5leafy vegetables, 3 tubers and 3 seeds [17].

\section{CONCLUSION}

The study focuses on the significance of wild fruit species as a source of nutrients for local people. Wild fruit plants can be included in agro-forestry and reforestation programme. These naturally occurring fruit plants are not only nutritionally and medicinally rich but also thrive well under adverse climatic conditions. In spite of their potential, these fruit plants are unattended both at scientific and farmers level. There is a need to collect and conserve these species before the threat of extinction.

\section{ACKNOWLEDGEMENT}

The authors are extremely thankful to council of scientific and industrial research (CSIR) for providing financial support.

\section{AUTHORS CONTRIBUTIONS}

All the authors have contributed equally.

\section{CONFLICT OF INTERESTS}

Declared none

\section{REFERENCES}

1. Sundriyal M, Sundriyal RC. Underutilized edible plants of the Sikkim Himalaya: need for domestication. Curr Sci 2003;85:731-93.

2. Vinceti B, Eyzaguirre P, Timothy J. The nutritional role of forest plant for rural communities. Human health and forests: a global overview of issues, practice and policy edited by CPJ Coler, Earthscan, London, UK; 2008.

3. Grivetti LE, Ogle BM. Value of traditional foods in meeting macro and micronutrient needs: the wild plant connection. Nutr Res Rev 2000;13:31-46.

4. Verheij EWM, Coronel RE. Plant resources of south-east asia: edible fruits and nuts. Pudoc, Wageningen publication, Netherlands; 1991

5. Rathore M. Nutrient content of important fruit trees from arid zone of Rajasthan. J Horti Forestry 2009;1:1103-9.

6. Samant SS, Dhar U. Diversity, endemism and economic potential of wild edible plants of Indian Himalaya. Int J Sust Dev World Ecol 1997;4:123-5.

7. Angami A, Padma G, Rethy P. Status and potential of wild edible plants of Arunachal Pradesh. Indian J Traditional Knowledge 2006;5:541-50

8. Hebbar SS, Harsha VH, Shripathi V, Hegde GR. Wild edible fruits of Dharwad, Karnataka. J Econ Taxon Bot 2010;27:982a.

9. Mahapatra A, Satarupa M, Uday B, Pratap P. Nutrient analysis of some selected wild edible fruits of deciduous forest of India; an explorative study towards non conventional bio-nutrition. Adv J Food Sci Tech 2012;4:15-21.

10. Sarma H, Kumar A, Borah S, Kumar D. Updated estimates of wild edible and threatened plants of Assam: a meta-analysis. Int J Bot 2010;6:414-23.

11. Ekka NS, Ekka A. Wild edible plants used by tribals of northeast Chhattisgarh (part-1). Res J Recent Sci 2016;5:127-31.

12. Bagra G, De LC, Singh VB. Collection and evaluation of some indigenous lesser known fruits of Arunachal Pradesh. Horticulture for sustainable income and environmental protection. Concept publications; 2006.

13. Ondachi PW. Nutritional studies of indigenous fruit trees in support of conservation, Annual research report, Part 1. African Academy of Sciences; 1999.

14. Halewood M, Baidu Forson JJ, Clancy E, Vodouhe RS. Cooperating to make the best use of plant genetic resources in west and central Africa: a regional imperative. Biodiversity international, Romeand CORAF/WECARD, Dakar; 2014.

15. Pretty J. Social capital and the collective management of resources. Science 2003;302:1912-5.

16. Yesodharan K, Sujana KA. Wild edible plants raditionally used by the tribes in parambikulam wildlife sanctuary, Kerala, India. Nat Prod Rad 2006;6:74-80.

17. Jose DK, Sasidharan N. Checklist of wild edible plants of Aralam wildlife sanctuary, Kerala, India. South Indian J Biol Sci 2016;2:141-4 